\title{
RESEARCH OF THE EFFECTS OF CONVERGENCE OF ECONOMIC POLICY IN REGIONAL AND INTERREGIONAL INTEGRATION ASSOCIATIONS
}

\author{
$\boldsymbol{V} . \boldsymbol{V}$. Krivorotov $^{1}, \mathrm{v} \_$krivorotov@mail.ru, \\ V.G. Mokhov ${ }^{2}$, mokhovvg@susu.ru, \\ O.Yu. Ivanova ${ }^{3}$, laptevaou@gmail.com, \\ O.Yu.Polyakova ${ }^{3}$, polya_o@ukr.net \\ ${ }^{1}$ Ural Federal University, Ekaterinburg, Russian Federation \\ 2 South Ural State University, Chelyabinsk, Russian Federation \\ ${ }^{3}$ Research Centre for Industrial Development Problems of NAS of Ukraine, Kharkov, \\ Ukraine
}

\begin{abstract}
The article is devoted to the analysis of the dynamics of macroeconomic indicators as the results of an economic policy in three integration associations: the European Union, the Organization for Economic Cooperation and Development, and BRICS. The aim of the study is to test the hypothesis of availability convergence of the results of economic policy, which is a consequence of the accession of countries to international unification. For the analysis, we used the models of $\sigma$-convergence (autoregression model, coefficient of variation), $\beta$-convergence (Barro and Sala-i-Martin, Baumol, Solow - Svan, Quadrado Roura). The presence and speed of convergence was studied before and after the accession of new countries to associations: according to the results of economic policy as a whole, in the field of labor, foreign economic activity, monetary and debt policy. It was established that in all associations there is a convergence in terms of per capita GDP, but differences in the level of development between countries persist even after unification. The study showed that the greatest number of convergence effects with equalization by individual indicators of economic policy is manifested in the European Union, the least effect - in the countries of the Organization for Economic Cooperation and Development. It is proved that the effectiveness of integration depends on its degree and is ensured by the presence of a mechanism for coordinating economic policy (in general or in separate areas), general requirements for economic security, joint action programs, including in the field of science and technology, as well as providing access to development resources for all countries of the association. The results of the study can be used to adjust the directions and methods of state and regional economic policies of countries included in the integration association.
\end{abstract}

Keywords: integration; economic policy; region; effect; $\sigma$-convergence, $\beta$-convergence.

\section{Introduction}

Integration processes spanning many countries of the world contribute to macroeconomic changes in those countries that have entered into integration associations, in their regions and in the associations themselves. The purpose of the formation of integration associations is to increase the level and quality of life of the population, stimulate self-development and self-regulation of national economic systems in their interaction. However, developing countries that enter into associations may also experience negative consequences of integration: the outflow of resources to developed countries, the effect of losses from an increase in the scale of production. Accordingly, the level of socioeconomic development countries of the integration association and their regions may vary 
significantly in different participating countries. One of the tools for studying interregional in the macroeconomic and mesoeconomic sense of the unevenness of socio-economic development are models based on the concept of convergence. The concept of convergence, which arose to explain the fast pace of development of developing countries, gradually spread to regional studies. The problems of heterogeneous socio-economic development of the regions are the subject of research by many scientists in the world (the United States assesses convergence between states [1], the European Union (EU) notes convergence as a criterion for the effectiveness of regional policy [2], uneven development of regions within the country was assessed in the United States [1], Russia [3], Ukraine [4, 5]), since the growth of heterogeneity contributes to the emergence of social tension and the activation of destructive processes. Convergence between countries and regions was dealt with by economists: R. Barro, J. Borts, D. Weil, A. Granberg, S. Drobyshevsky, D. Zverev, N. Kizim, T. Klebanova, E. Kolomak, O. Lugovoi , G. Mankiw, D. Romer, T. Swan, R. Solow, I. Stolovyanskaya, A. de la Fuente, P. Evans and others. Convergence models were developed and studied by R. Solow [6]; G. Mankiw, D. Weil, D. Romer [7]; R. Barro, X. Sala-i-Martin [8]. However, the issues of assessing the convergence of the results of economic policies of countries that have joined the integration associations have not been fully studied. The question is not fully clarified whether convergence intensifies after the formation of an integration association or after a group of countries joins an existing association. The purpose of this study is to test the hypothesis of convergence of economic policy results, which is a consequence of countries joining the union.

\section{The Theoretical Basis of Convergence}

Among the theories of regional development that study convergence (Latin: convergens - matching), one should single out the neoclassical theory of economic growth, which is based on spatial and production factors for the development of the potential of territories. The uneven development of (macro) regions is explained by temporary differences due to an ineffective response to external shocks. At the same time, a tendency towards a decrease in differentiation and a convergence of levels of economic development is assumed. Representatives of this theory are R. Barro, J. Borts, D. Weil, G. Mankiw, D. Romer, T. Swan, R. Solow, A. de la Fuente, P. Evans and others. Convergence between countries with different the level of socio-economic development in the twentieth century R. Solow [6]. The scientist proposed a neoclassical model of economic growth, which involves reducing the gaps between the levels of socio-economic development of developing and developed countries due to faster rates of economic growth in countries "located far from a stationary state (a state in which the capital-labor ratio is at a constant level), according to compared with countries lying closer to it" [9]. Subsequently, G. Mankiw, D. Romer and D. Weil [7, 10] added human capital as a necessary condition for economic growth in the R. Solow convergence model. The model includes the equal contributions of physical and human capital to GRP for all countries, the depreciation rate, the population growth rate of countries and scientific and technical progress, and the savings rate. Redistribution of human capital contributes to an increase in production without the need to increase costs. On this basis, P. Romer [10] and other scientists have built growth models in which the effect of scale increases based on external effects.Based on the essence of convergence as a process of convergence of different economies (or regions) 
due to higher economic growth rates in countries with low per capita incomes and their potential alignment with developed countries [11], this model is used in accordance with two concepts: $\sigma$-convergence, reflecting a decrease in the time spread of the development levels of countries, when the dispersion of indicators development is reduced, and $\beta$ convergence, when the pace of economic growth of less developed countries (regions) exceeds the pace of developed countries (regions), resulting in a tendency to equalize levels of economic development $[8,12,13]$. The interconnection of these concepts is manifested in the fact that $\beta$-convergence is a necessary but insufficient condition for $\sigma$-convergence. At the same time, the trends of reducing inequality between countries (regions) during $\beta$ convergence may be distorted, and due to random shocks, the differences may temporarily increase.

The studies of R. Barro and X. Sala-i-Martin [8] indicate the possibility of unconditional and conditional convergence. Unconditional $\beta$-convergence implies a proportional growth of economies (regions) with a homogeneous structure of the economy and temporary differences in levels of socio-economic development due to different income levels at the initial stage of development, which is impossible in the face of uneven economic, technical, technological, innovative, and infrastructural factors. Conditional $\beta$-convergence implies different trajectories of proportional growth of different countries (regions) depending on the influence of specific development factors in each country (region) [3]. A significant convergence factor, according to R. Barro and X. Sala-i-Martin [8], is the movement of capital. The concept involves the transfer of capital from more developed countries (regions) to less developed ones due to a slowdown in the former and increase return on investment in the latter. This in turn contributes to an increase in the rate of production per unit of capital cost. Low labor costs in developing countries lead to greater returns on capital investment, which determines convergence.

The advantages of these models are: firstly, the complementarity of human and physical capital of the association, which allows you to compensate for the lack of one of the components of the country; secondly, the model involves measuring the speed and time of convergence, which allows you to develop managerial decisions for the sustainable economic development of the country. Among the shortcomings of convergence models at the meso-economic level, W. Isard notes the lack of consideration of spatial factors of regional development [14]. Spatial dependence of regions is considered in the research of J. Jacobs [15], where the effect of the spatial proximity of the regions is manifested in the exchange of knowledge, ideas between different sectors of the economy and, as a consequence, in development. Such effects from the collaboration between business, science, and financial enterprises stimulate the diffusion of innovations [16, 17]. This thesis is developing in the new economic geography.

Consequently, integration associations as a system of socially and economically interconnected countries, in which mechanisms of interaction between countries and their regions are provided, should promote convergence in various areas of economic development. 


\section{Materials and Methods}

Convergence assessment was carried out for the countries of the European Union (EU), the Organization for Economic Cooperation and Development (OECD) and the BRICS countries. The study covered the period from 1995 to 2018, with the exception of some indicators that were available only for a shorter period of time. For calculations, we used data from the World Bank, the International Monetary Fund, the UN, the UN Conference on Industry and Trade (UNCTAD), Eurostat, the International Labor Organization (ILO), the OECD statistical base, as well as national statistical services, if there were no or were no data in international statistics missed.

The study included all EU countries at the end of 2019, with the exception of Cyprus and Malta, taking into account the size of these economies, their island position and the ensuing features. Since the final exit of Great Britain from the EU was planned only at the beginning of 2020, the data of this country were also taken into Attention. In addition, by virtue of the entry into force of the Cooperation Agreement between Ukraine and the EU, data on the results of economic activity of Ukraine were also considered in assessing convergence for the entire period of the study. A total of 27 countries were considered. Throughout the entire study period, the EU expanded three times: in 2004 Poland, the Czech Republic, Hungary, Estonia, Latvia, Lithuania, Slovenia and Slovakia; in 2007 Bulgaria and Romania, and in 2013 Croatia. Given that the time between the first two extensions is small compared to the entire study period, the extensions of 2004 and 2007 were considered as one. The period after the accession of Croatia was not distinguished as a separate period, since the convergence effect for such a short period of time could not yet be significant, therefore, when studying convergence during 2004-2018 years Croatia was excluded from consideration. Also, Ukraine was not considered in this period, since it is not a member of the EU.

Convergence assessments of economic policy outcomes were carried out for the entire set of 36 OECD countries. For 1995-2018 the most widespread was the entry into the OECD in 2010 of Israel, Chile, Estonia and Slovenia; therefore, it was 2010 that was considered as the border of two periods. Slovakia became a member of the OECD in 2000, so it was assigned to the main group of participating countries. The data of Latvia, which joined in 2016 and in 2018, was not considered in the convergence study for the period 2010-2018. For the EU and OECD, the convergence study was carried out in two sections:

- for the entire period 1995-2018 for a group of all countries;

- separately for the period before and after expansion for the groups:

a) of all countries,

b) for the "old" members of the association (those that were members of the association before the expansion),

c) for the group of "new" members. For each selected indicator for the EU and OECD countries, convergence hypotheses were tested in seven groups of countries. The creation in 2006 of an association of 5 BRICS countries naturally divided the study period into two periods: 1995-2005 and 2006-2018, the whole period was also considered.

The main indicator that is usually used to check for convergence in a group of countries and most reflects the level of economic development of countries is the volume of GDP 
per capita. To ensure the most comparable results, per capita GDP values calculated at current purchasing power parity were used. In addition, the unemployment rate, as a percentage of the economically active population according to the ILO methodology, and the inflation rate measured by the consumer price index by the end of the year were used to characterize the results of economic policy as a whole. The characteristic of the economic policy in the field of personal income was the average annual wage converted from national monetary units to international dollars at purchasing power parity. Considering that one of the main goals of creating and joining integration associations is to expand and simplify foreign economic activity, export and import per capita (to exclude economies of scale) in US dollars and their ratio to the country's GDP in \% were considered as characteristics of foreign economic policy .

In addition, participation in integration associations often involves the free movement of capital and the simplification of technology transfer, which should lead to equalization in the export of high-tech goods. Therefore, the study also included indicators of the volume of exports of high-tech goods (according to the UNIDO methodology) in US dollars per capita and its share in the total export of industrial goods. However, the study of convergence on this indicator of economic policy was possible only since 2007, therefore, in this case, only one time period was considered, which practically corresponds to the period after the association for all associations.

Finally, the most general characteristic of the debt component of economic policy in the study is the size of gross public debt in \% of GDP. For the results of economic policy, expressed in monetary units per capita, both hypotheses about the presence of $\sigma$-convergence and $\beta$-convergence were tested. For indicators expressed as a percentage, the use of $\beta$-convergence models does not make sense, so for them only the hypothesis of $\sigma$-convergence was tested, which implies the achievement of a certain average, target, or safe level.

\section{Convergence Estimates}

Convergence estimates are presented in tables separately for integration associations. They show results only regarding the detected effects of convergence. All other convergence hypotheses were not confirmed at a sufficient level, or the divergence hypothesis was confirmed, i.e. discrepancy of results that will be indicated in each case.

\subsection{Convergence between EU Countries}

The convergence of EU countries according to the results of economic policy is the most expected, because, firstly, accession to the EU itself requires the country to fulfill certain requirements regarding the state of its economy, and secondly, accession opens up access to the common labor market, finance and trade facilitation within associations. Therefore, the convergence of the EU countries has been the subject of a large number of studies that partially supported the hypothesis. The results of the assessment of the convergence of the EU countries according to the results of economic policy are shown in table 1 . The most expected result is the presence of both $\sigma$-convergence and $\beta$-convergence in terms of GDP among the "new" EU countries. It should be noted that prior to joining the EU $\sigma$-convergence was not observed among these countries, however, the conclusion 
about divergence cannot be drawn either, since has a low coefficient of determination $\left(R^{2}=0.33\right)$. At the same time, the presence of a weak, decreasing divergences in the group of all countries for the entire period 1995-2018. $\left(b=1.05 ; R^{2}=0.97\right)$, both before $\left(b=1.10 ; R^{2}=0.93\right)$, and after the expansion of the $\mathrm{EU}\left(b=1.04 ; R^{2}=0.87\right)$, as well as in all periods for the group of "old" EU members. This suggests that the gap in the level of development between the EU countries remains. At the same time, the decrease in the coefficient of variation in the $\mathrm{EU}$ as a whole with the maximum value is 0.57 in 2000 to 0.44 by 2018, while the coefficient of variation for the group of "old" EU members is lower than for the group of "new" members.

In the average annual wage level in all groups of EU countries, a stable divergence was observed in all periods under consideration. Moreover, the divergence rate was the highest in the group of "new" EU members in the period after accession $\left(b=1.12 ; R^{2}=0.95\right)$, and the lowest in the group of "old" members in the period before expansion $(b=1.04$; $\left.R^{2}=0.84\right)$.

However, a slight decrease in the coefficient of variation is observed throughout the entire period under consideration. Weak $\beta$-convergence in terms of average annual wages is observed only when considering all EU countries as one group in each of the periods. So for the entire period 1995-2018, the convergence rate was $\beta=0.033(t=-5.6)$, before expansion $\beta=0.026(t=-5.1)$, and after $\beta=0.061(t=-5.09)$, however, the coefficients of determination of the models $(0.53-0.59)$ are insufficient to make this effect stable. However, the free movement of labor within the EU has a positive impact on the labor market in each country, as evidenced by the convergence of unemployment rates (Table 1). The fact that the unemployment rate is one of the criteria for internal imbalances controlled by the European Commission also played a role here.

Therefore, the employment policy pursued by the EU countries is aimed at keeping this indicator within $10 \%$. It should be noted that at the time of EU enlargement in 2004 in most of the acceding countries this threshold was exceeded (with the exception of the Czech Republic, Hungary and Slovakia). At the end of 2018, excess was observed only in Spain, Greece and Italy. Significant fluctuations in the unemployment rate in these countries led to the fact that the coefficient of variation does not decrease constantly, but in the last 3 years it even increased, it was the smallest (0.33) at the beginning of the global crisis, in 2008. As for the inflation rate, this indicator is also one of the imbalances controlled by the European Commission, and is the subject of constant attention of the Eurocentral Bank and the governments of individual countries. The coefficient of variation in the inflation rate since 2002 has been more than 0.02 , and in general, after expansion, the inflation rate in all countries is between $95.5 \%$ and $110 \%$ (with the exception of 115.4 $\%$ in Latvia in 2008). With such it does not make sense to talk about the presence of any trends on the whole, and slight fluctuations are observed in individual countries. Thus, EU accession and the need for a coherent monetary policy led to the extreme form of $\beta$ convergence - the absence of significant fluctuations both within the group and in time. A distinctive feature of the EU is the convergence in terms of high-tech exports, in particular in the group of "new" members. This indicates the effectiveness of the functioning of a single research and educational space and technology transfer to the EU. 
Table 1

EU Policy Convergence Assessment

\begin{tabular}{|c|c|c|c|c|}
\hline $\begin{array}{l}\text { Result of the policy, model, } \\
\text { group, period }\end{array}$ & \multicolumn{4}{|c|}{ Convergence Indicators } \\
\hline \multicolumn{5}{|c|}{ PPP GDP per capita } \\
\hline \multicolumn{5}{|l|}{$\sigma$-convergence $(1)$} \\
\hline$\ll$ New», after 2004 & $b=0.968$ & $t=27.967$ & $p<0.001$ & $R^{2}=0.81$ \\
\hline \multicolumn{5}{|c|}{$\beta$-convergence, Barro model (3) } \\
\hline$\ll \mathrm{New}$, until 2004 & $\begin{array}{l}b=-0.05 \\
\beta=0.063\end{array}$ & $t=-4.47$ & $p=0.004$ & $R^{2}=0.77$ \\
\hline$\ll \mathrm{New} \gg$, after 2004 & $\begin{array}{l}b=-0.05 \\
\beta=0.087\end{array}$ & $t=-5.84$ & $p=0.001$ & $R^{2}=0.85$ \\
\hline \multicolumn{5}{|c|}{ Unemployment rate, $\%$} \\
\hline all countries, 1995-2018 & $b=0.965$ & $t=19.167$ & $p<0.001$ & $R^{2}=0.60$ \\
\hline$\ll$ Old $\gg$, until 2004 & $b=0.854$ & $t=45.737$ & $p<0.001$ & $R^{2}=0.98$ \\
\hline all countries, after 2004 & $b=0.97$ & $t=14.107$ & $p<0.001$ & $R^{2}=0.67$ \\
\hline$\ll$ Old $\gg$, after 2004 & $b=0.986$ & $t=13.572$ & $p<0.001$ & $R^{2}=0.81$ \\
\hline \multicolumn{5}{|c|}{$\begin{array}{l}\text { Export, USD US per capita } \\
\end{array}$} \\
\hline \multicolumn{5}{|c|}{$\beta$-convergence, Barro model (3) } \\
\hline all countries, 1995-2018 & $\begin{array}{l}b=-0, .18 \\
\beta=0.023\end{array}$ & $t=-5.14$ & $p<0.001$ & $R^{2}=0.52$ \\
\hline$\ll$ New», after 2004 & $\begin{array}{l}b=-0.022 \\
\beta=0.026\end{array}$ & $t=-3.84$ & $p=0.005$ & $R^{2}=0.65$ \\
\hline \multicolumn{5}{|c|}{$\begin{array}{l}\text { Import, USD US per capita } \\
\end{array}$} \\
\hline \multicolumn{5}{|c|}{$\beta$-convergence, Barro model (3) } \\
\hline all countries,1995-2018 & $\begin{array}{l}b=-0.018 \\
\beta=0.023\end{array}$ & $t=-5.38$ & $p<0.001$ & $R^{2}=0.55$ \\
\hline all countries, until 2004 & $\begin{array}{l}b=-0.030 \\
\beta=0.035\end{array}$ & $t=-5.97$ & $p<0.001$ & $R^{2}=0.62$ \\
\hline$\ll$ New», after 2004 & $\begin{array}{l}b=-0.019 \\
\beta=0.023\end{array}$ & $t=-3.08$ & $p=0.015$ & $R^{2}=0.54$ \\
\hline \multicolumn{5}{|c|}{ High-tech exports, USD US per capita } \\
\hline \multicolumn{5}{|c|}{$\beta$-convergence, Barro model (3) } \\
\hline all countries, 2007-2018 & $\begin{array}{l}b=-0.035 \\
\beta=0.044\end{array}$ & $t=-5.08$ & $p<0.001$ & $R^{2}=0.52$ \\
\hline$\ll$ New», 2007-2018 & $\begin{array}{l}b=-0.037 \\
\beta=0.047\end{array}$ & $t=-4.43$ & $p=0.002$ & $R^{2}=0.71$ \\
\hline \multicolumn{5}{|c|}{ High-tech exports, $\%$ of industrial exports } \\
\hline$\ll$ New», 2007-2018 & $b=-0.912$ & $t=-16.0$ & $p<0.001$ & $R^{2}=0.56$ \\
\hline \multicolumn{5}{|c|}{ Gross public debt, $\%$ of GDP } \\
\hline all countries, 2000-2003 & $b=0.957$ & $t=81.28$ & $p<0.001$ & $R^{2}=0.90$ \\
\hline «New», 2000-2003 & $b=0.817$ & $t=14.36$ & $p<0.001$ & $R^{2}=0.68$ \\
\hline
\end{tabular}

Note. Types of convergence are indicated only where discrepancies are possible.

The same in the following tables. 


\subsection{OECD Convergence}

The revealed convergence effects in the group of OECD countries are shown in Table 2.

Table 2

Convergence Assessment of Economic Policy Results in OECD Countries

\begin{tabular}{|c|c|c|c|c|}
\hline $\begin{array}{l}\text { Result of the policy, model, } \\
\text { group, period }\end{array}$ & \multicolumn{4}{|c|}{ Convergence Indicators } \\
\hline \multicolumn{5}{|c|}{ PPP GDP per capita } \\
\hline \multicolumn{5}{|l|}{$\beta$-convergence, Barro model (3) } \\
\hline all countries, 1995-2018 & $\begin{array}{l}b=-0.019 \\
\beta=0.026\end{array}$ & $t=-6.98$ & $p<0.001$ & $R^{2}=0.59$ \\
\hline$\ll$ New», until 2004 & $\begin{array}{l}b=-0.032 \\
\beta=0.043\end{array}$ & $t=-2.21$ & $p=0.16$ & $R^{2}=0.71$ \\
\hline \multicolumn{5}{|c|}{ PPP average annual salary } \\
\hline \multicolumn{5}{|c|}{$\beta$-convergence, Barro model (3) } \\
\hline all countries, 1995-2018 & $\begin{array}{l}b=-0.018 \\
\beta=0.023\end{array}$ & $t=-6.93$ & $p<0.001$ & $R^{2}=0.61$ \\
\hline all countries, until 2007 & $\begin{array}{l}b=-0.02 \\
\beta=0.024\end{array}$ & $t=-6.89$ & $p<0.001$ & $R^{2}=0.61$ \\
\hline$\ll$ Old $\gg$, until 2007 & $\begin{array}{l}b=-0.017 \\
\beta=0.019\end{array}$ & $t=-5.58$ & $p<0.001$ & $R^{2}=0.54$ \\
\hline «New», until 2007 & $\begin{array}{l}b=-0.038 \\
\beta=0.054\end{array}$ & $t=-5.67$ & $p=0.11$ & $R^{2}=0.97$ \\
\hline$\ll$ New», after 2007 & $\begin{array}{l}b=-0.036 \\
\beta=0.043\end{array}$ & $t=-4.97$ & $p=0.04$ & $R^{2}=0.93$ \\
\hline \multicolumn{5}{|c|}{ Unemployment rate, $\%$} \\
\hline all countries, $1995-2018$ & $b=0.967$ & $t=21.22$ & $p<0.001$ & $R^{2}=0.63$ \\
\hline all countries, until 2007 & $b=0.944$ & $t=18.88$ & $p<0.001$ & $R^{2}=0.65$ \\
\hline$\ll$ Old $\gg$, after 2007 & $b=0.935$ & $t=20.85$ & $p<0.001$ & $R^{2}=0.70$ \\
\hline \multicolumn{5}{|c|}{ Unemployment rate, $\%$} \\
\hline all countries, 1995-2018 & $b=0.793$ & $t=26.12$ & $p<0.001$ & $R^{2}=0.958$ \\
\hline all countries, until 2007 & $b=0.818$ & $t=19.26$ & $p<0.001$ & $R^{2}=0.94$ \\
\hline$\ll$ Old $\gg$, after 2007 & $b=0.824$ & $t=18.34$ & $p<0.001$ & $R^{2}=0.94$ \\
\hline «New», after 2007 & $b=0.453$ & $t=6.78$ & $p<0.001$ & $R^{2}=0.71$ \\
\hline \multicolumn{5}{|c|}{ Export, USD US per capita } \\
\hline \multicolumn{5}{|l|}{$\sigma$-convergence $(1)$} \\
\hline$\ll$ New», until 2007 & $b=0.979$ & $t=8.71$ & $p<0.001$ & $R^{2}=0.59$ \\
\hline \multicolumn{5}{|c|}{ Export, $\%$ of GDP } \\
\hline$\ll$ New», until 2007 & $b=0.915$ & $t=11.72$ & $p<0.001$ & $R^{2}=0.55$ \\
\hline \multicolumn{5}{|c|}{ Gross public debt, $\%$ of GDP } \\
\hline$\ll$ New», 2000-2006 & $b=0.989$ & $t=25.88$ & $p<0.001$ & $R^{2}=0.62$ \\
\hline
\end{tabular}

Estimation of the $\sigma$-convergence in terms of per capita GDP showed a fairly stable divergence in all studied periods and in all groups of OECD countries. At the same time, the coefficient of variation steadily decreased from 0.46 in 1995 to 0.37 in 2018, which can 
be considered as a sign of convergence of countries. At the same time, this was achieved to a greater extent due to the low coefficient for the group of acceding countries $(0.16$ in 2018). However, the weak effect of $\beta$-convergence observed in the entire group of countries (see Table 2) before the new members joined, it disappeared in the period after 2010, and the convergence among the "new" members greatly weakened, so the use of the Barro, Sala-i-Martin model has become impossible.

A feature of the group of OECD member countries is the presence of stable convergence in terms of average annual wages. The basis for the presence of $\sigma$-convergence in this case is a steady decrease in the coefficient of variation to 0.32 in 2018. In addition, as shown by the data in Table $2, \beta$-convergence is observed both for the whole group as a whole for the period under review and for the group of acceding countries. In the EU, this effect was much weaker.

Unlike the EU and despite the fact that most EU countries are also OECD members, one should note the strong convergence in inflation observed until 2009. After the introduction of new members, this effect was lost, which is a consequence of achieving almost complete uniformity, precisely, coefficient variations decreased from 0.15 in 1995 to 0.02 in 2018. Convergence according to the results of foreign economic policy in the OECD countries is weak. Therefore, only in terms of exports (both per capita and in \% of GDP) $\sigma$-convergence appears. At the same time, a rather low quality indicator of the model $\left(R^{2}=0.55\right)$ indicates a weak expression of this effect. Moreover, the effect available before accession was lost, and the coefficient of variation tends to increase throughout the analysis period (from 0.53 in 1995 to 0.7 in 2018). The increase in differences between countries is confirmed by the presence of stable divergence in terms of per capita exports for the group of acceding countries $\left(\beta=-0.04 ; R^{2}=0.71\right)$. As regards the import indicators, a stable $\sigma$-divergence was observed in the share of imports in GDP for the entire group of OECD countries, as well as for the group of "old" members for the entire period under review and separately for the period before the accession of new members $\left(b=1.03 ; R^{2}=0.61 \ldots 0.89\right)$. At the same time, the coefficient of variation also increases (from 0.47 to 0.64 ). The same is true for the volume of imports per capita, and in this case, the coefficient of variation reached 1,34 . Since the OECD does not implement joint research projects as large as they do in the EU, the lack of convergence in terms of technology transfer and alignment of high-tech exports is not unexpected. However, it is worth noting that the coefficient of variation for both indicators of high-tech exports in OECD countries is constantly greater than 1 and has no tendency to change. Thus, in terms of high-tech exports per capita, extreme positions are consistently occupied by Chile and Turkey (for example, 36.3 and 37.9 US dollars in 2018, respectively) on the one hand, and Ireland (7519.1 US dollars) and the Netherlands (\$4978.9), on the other hand. Korea holds the lead in the share of high-tech exports in the export of industrial goods $(36.3 \%)$, while Turkey $(2.3 \%)$ is a stable outsider. Thus, the lack of a coherent policy in the field of science and innovation impedes the convergence of the countries of association.

The debt policy of OECD member countries differs significantly in results, which is confirmed by the stable trend of $\sigma$-divergence. So, for the entire period 2000-2018, as a whole, the divergence coefficient for the association was $b=1.04 ; R^{2}=0.94$, and the convergence among the "new"members observed before joining was significantly weakened (Table 2). 


\subsection{BRICS Convergence}

Of the considered associations of countries, convergence effects were found to the least extent within the framework of BRICS. Convergence estimates based on the economic policies of the BRICS countries are shown in Table 3. Unlike previous associations in the BRICS countries after the creation of the unification, the persistent effect of $\sigma$-divergence in terms of per capita GDP (Table 3), which was observed before, disappeared. Although convergence has not been achieved, the coefficient of variation tends to decrease (from 0.66 in 1995 to 0.46 in 2018). In addition, after the merger, the rate of $\beta$-convergence increased, which can be considered a positive result of the merger. Convergence in terms of average annual wages was not evaluated, as data for some countries are not available.

Table 3

Evaluation of the convergence of economic policy outcomes in the BRICS countries

\begin{tabular}{|c|c|c|c|c|}
\hline $\begin{array}{l}\text { Result of the policy, model, } \\
\text { group, period }\end{array}$ & \multicolumn{4}{|c|}{ Convergence Indicators } \\
\hline \multicolumn{5}{|c|}{ PPP GDP per capita } \\
\hline \multicolumn{5}{|l|}{$\beta$-convergence, Barro model (3) } \\
\hline $1995-2018$ & $\begin{array}{l}b=-0.029 \\
\beta=0.046\end{array}$ & $t=-2.68$ & $p=0.081$ & $R^{2}=0.70$ \\
\hline after merging & $\begin{array}{l}b=-0.035 \\
\beta=0.045\end{array}$ & $t=-1.95$ & $p=0.15$ & $R^{2}=0.56$ \\
\hline \multicolumn{5}{|c|}{ Export, USD US per capita } \\
\hline \multicolumn{5}{|l|}{$\sigma$-convergence $(1)$} \\
\hline $1995-2018$ & $b=0.955$ & $t=11.07$ & $p<0.001$ & $R^{2}=0.65$ \\
\hline \multicolumn{5}{|c|}{$\beta$-convergence, Barro model (3 } \\
\hline $1995-2018$ & $\begin{array}{l}b=-0.021 \\
\beta=0.028\end{array}$ & $t=-2.18$ & $p=0.12$ & $R^{2}=0.61$ \\
\hline after merging & $\begin{array}{l}b=-0.020 \\
\beta=0.022\end{array}$ & $t=-1.79$ & $p=0.17$ & $R^{2}=0.52$ \\
\hline \multicolumn{5}{|c|}{ Export as \% of GDP } \\
\hline $1995-2018$ & $b=0.945$ & $t=15.02$ & $p<0.001$ & $R^{2}=0.55$ \\
\hline \multicolumn{5}{|c|}{ Import, USD US per capita } \\
\hline \multicolumn{5}{|l|}{$\sigma$-convergence $(1)$} \\
\hline $1995-2018$ & $b=0.954$ & $t=12.23$ & $p<0.001$ & $R^{2}=0.68$ \\
\hline \multicolumn{5}{|c|}{$\beta$-convergence, Barro model (3) } \\
\hline $1995-2018$ & $\begin{array}{l}b=-0.027 \\
\beta=0.041\end{array}$ & $t=-3.09$ & $p=0.05$ & $R^{2}=0.76$ \\
\hline \multicolumn{5}{|c|}{ Gross public debt, in \% of GDP } \\
\hline after merging & $b=0.984$ & $t=28.11$ & $p<0.001$ & $R^{2}=0.63$ \\
\hline
\end{tabular}

Since a single labor market is not provided for in the BRICS, and taking into account the geographic remoteness of countries, it is impossible, the convergence in unemployment could only be the result of accelerating the economic development of countries as a result 
of unification. However, this effect is not observed. Moreover, for 1995-2018, there is an increase in the coefficient of variation for this indicator to 0.92 , which is mainly explained by very large values in South Africa (within 22-27\%).

The coefficient of variation in terms of inflation since 2000 has not exceeded 0,1 , which indicates the achievement of uniformity in a group of countries. At the same time, the inflation values themselves range from $102-111 \%$. However, one cannot speak about the influence of the fact of unification in this case, since these values were achieved long before it. The achievement of the association's goals in terms of enhancing cross-country trade is evidenced by the revealed effects of convergence in terms of exports and imports. In addition to the effects shown in Table 3, it should also be noted a significant decrease in the coefficient of variation in terms of per capita exports (from 0.86 to 0.63 for 1995-2018) and per capita imports (from 0.82 to 0.46 ) and also the fact that $\beta$-convergence appeared precisely after the creation of the association. In addition, since 2003, the coefficients of variation in the proportions of exports and imports in GDP stabilized at 0.3. Moreover, in all BRICS countries, the share of exports in GDP exceeds the share of imports, which can be considered a positive result of foreign economic policy. However, according to the characteristics of export quality, countries differ quite significantly. Thus, the coefficient of variation in the volume of exports of high-tech goods per capita since 2009 is at 1.5, which is explained by a significant gap between China and other countries (in 2017, the indicator of China amounted to 471.9 US dollars per capita, and in India 11.3 US dollars). A similar picture is observed in terms of the share of high-tech exports, which in China is up to $30-32 \%$, and in South Africa 5-6\%. Thus, it is impossible to talk about any positive effect after the creation of the association in the direction of technology transfer and joint development. In contrast to the EU and OECD countries, where the $\sigma$-convergence disappeared in terms of gross public debt in \% of GDP after expansion, in the BRICS countries after the creation of the association (and after the acute phase of the 2008-2009 crisis), the coefficient of variation also decreases and actually $\sigma$-convergence. This is mainly due to the absence of extreme values of public debt, which are observed in some EU and OECD countries, but indirect positive effects from the expansion of international trade can be assumed.

\section{Conclusions}

The study allows us to draw a number of conclusions about the effectiveness of associations. The most effective, from the point of view of achieving convergence and alignment on individual indicators of economic policy from the considered integration associations, is the EU. The conditions that ensured these results are, on the one hand, the requirements of the European Commission, to which, to one degree or another, the economic policies of the member countries must comply. On the other hand, numerous joint action programs, EU structural funds, as well as the availability of the common labor market, which contributes to convergence in various fields from employment to the development of hightech industries. At the same time, there remains a distinction between countries that, when they joined the EU, had a lower level compared to the "old" EU members, which did not decrease (or very slowly decrease) over time, despite the convergence. The effects of convergence are least pronounced in OECD countries, since the quality indicators of the constructed models are much lower than in other associations. This suggests the need 
for additional research and the search for possible convergence conditions or the use of another basic development model. However, since the majority of OECD countries are EU countries, the use of conditional convergence seems to be the most promising.

In the BRICS countries, convergence effects related to the foreign economic component of the economic policies of countries were also achieved, which allows us to talk about achieving the goals of the association. However, indirect, long-term effects are not observed, therefore, strategies should be developed to increase the effectiveness of the association joint, to a greater extent integrated development in various directions.

Thus, the effectiveness of integration depends on its degree and is ensured by the presence of a mechanism for coordinating economic policy (as a whole or in separate areas), general requirements for economic security, and joint action programs, including in the field of science and technology, as well as providing access to development resources for all countries of the association.

\section{References}

1. Young A., Higgins M., Levy D. Sigma Convergence Versus Beta Convergence: Evidence from U.S. County-Level Data. Journal of Money, Credit and Banking, 2008, vol. 40, no. 5, pp. 1083-1093. DOI: 10.1111/j.1538-4616.2008.00148.x

2. De Michelis N. Regional Convergence: a Relevant Measure of Policy Success? CESifo Forum, 2008, no. 1, pp. 10-13.

3. Kolomak E. A. [Models of Regional Policy: Convergence or Divergence]. Bulletin of NSU. Series "Socio-Economic Sciences", 2009, vol. 9, no. 1, pp. 113-120. (in Russian)

4. [Unevenness and Cyclical Dynamics of Socio-Economic Development of Regions: Assessment, Analysis, Forecasting]. Eds. T. S. Klebanova, N. A. Kizima, Kharkov, Publishing House "ENGEC", 2012. (in Russian)

5. Storonyans'ka I. [Regional Development of Ukraine: Problems of Integration and Convergence]. Lviv, Institute for Regional Studies of NAS of Ukraine, 2010. (in Ukrainian)

6. Solow R. M. A Contribution to the Theory of Economic Growth. The Quarterly Journal of Economics, 1956, vol. 70, no. 1, pp. 65-94.

7. Mankiw G. A., Weil D., Romer D. Contribution to the Empirics of Economic Growth. The Quarterty Journal of Economics, 1992, vol. 107, no. 2, pp. 407-438. DOI: $10.2307 / 2118477$

8. Barro R. J., Sala-i-Martin X. Economic Growth and Convergence across the United States, NBER Working Paper 3419. Cambridge, NBER, 1990. Working Paper 3419 DOI: $10.3386 /$ w3419

9. Tolmachev M. N. Theoretical and Empirical Approaches to the Convergence of Agricultural Production. [Bulletin of the Volgograd State University. Series 3. Economics. Ecology], 2012, no. 1 (20), pp. 193-199. (in Russian) 
10. Romer P. M. Increasing Returns and Long-Run Growth. Journal of Political Economy, 1986, vol. 94, no. 4, pp. 1002-1037.

11. Wikipedia, available at: https://ru.wikipedia.org/ (accessed on 25 June 2020)

12. Sala-i-Martin X. Regional Cohesion: Evidence and Theories of Regional Growth and Convergence. European Economic Review, 1996, vol. 40, no. 6, pp. 1325-1352. DOI: 10.1016/0014-2921(95)00029-1

13. Sala-i-Martin X. The Classical Approach to Convergence Analysis. The Economic Journal, 1996, vol. 106, no. 473, pp. 1019-1036.

14. Isard W. Methods of Regional Analysis: an Introduction to Regional Science. Cambridge, the M.I.T. Press, 1962.

15. Jacobs J. The Economy of Cities. New York, Vintage Books, 1969.

16. Golovina S. G., Pugin S. V. Assessment of Convergence (Divergence) Processes in the Development of Areas of the Kurgan Region. [Bulletin of Altai State Agrarian University], 2014, no. 12 (122), pp. 162-166. (in Russian)

17. Henderson J. V. Marshall's Scale Economies. Journal of Urban Economics, 2003, vol. 53, no. 1, pp. 1-28. DOI: 10.1016/S0094-1190(02)00505-3

Vadim V. Krivorotov, DSc (Economics), Professor, Department of Economic Security of Industrial Complexes, Ural Federal University (Ekaterinburg, Russian Federation), v_krivorotov@mail.ru.

Veniamin G. Mokhov, DSc (Economics), Professor, Department of Mathematical and Computer Modelling, South Ural State University (Chelyabinsk, Russian Federation), mokhovvg@susu.ru.

Olga Yu. Ivanova, DSc (Economics), Associate Professor, Sector "Problems of Regional Development and Decentralization", Research Centre for Industrial Development Problems of NAS of Ukraine (Kharkov,Ukraine), laptevaou@gmail.com.

Olga Yu. Polyakova, PhD (Economics), Associate Professor, Sector "Problems of Regional Development and Decentralization", Research Centre for Industrial Development Problems of NAS of Ukraine (Kharkov,Ukraine), polya_o@ukr.net.

Received May 7, 2020 


\title{
ИССЛЕДОВАНИЕ ЭФФЕКТОВ КОНВЕРГЕНЦИИ ЭКОНОМИЧЕСКОЙ ПОЛИТИКИ В РЕГИОНАЛЬНЫХ И МЕЖРЕГИОНАЛЬНЫХ ИНТЕГРАЦИОННЫХ ОБЪЕДИНЕНИЯХ
}

\author{
В. В. Криворотов, В. Г. Мохов, О. Ю. Иванова, О. Ю. Полякова
}

\begin{abstract}
Статья посвящена анализу динамики макроэкономических показателей как результатов проводимой экономической политики в трех интеграционных объединениях: Европейском Союзе, Организации экономического сотрудничества и развития, БРИКС. Целью исследования является проверка гипотезы о наличии конвергенции результатов экономической политики, которая является следствием присоединения стран к международному объединению. Для анализа использованы модели $\sigma$-конвергенции (модель авторегрессии, коэффициент вариации), $\beta$-конвергенции (Барро и Сала-иМартина, Баумоля, Солоу - Свана, Квадрадо - Роура). Исследованы наличие и скорость конвергенции до и после присоединения к объединениям по результатам экономической политики в целом, в сфере труда, внешнеэкономической деятельности, монетарной и долговой политики. Установлено, что во всех объединениях наблюдается конвергенция по объему ВВП на душу населения, но различия в уровне развития между странами сохраняются и после объединения. Исследование показало, что наибольшее количество конвергенционных эффектов с выравниванием по отдельным показателям экономической политики проявляется в Европейском Союзе, наименьший эффект - в странах Организации экономического сотрудничества и развития. Доказано, что эффективность интеграции зависит от ее степени и обеспечивается наличием механизма согласования экономической политики (в целом или по отдельным направлениям), общих требований экономической безопасности, программ совместных действий, в том числе в сфере науки и технологий, а также обеспечением доступа к ресурсам развития для всех стран объединения. Результаты исследования могут быть использованы для корректировки направлений и методов государственной и региональной экономической политики стран, входящих в интеграционное объединение.
\end{abstract}

Ключевые слова: интеграция; экономическая политика; регион; эфбект; бконвергениия; $\beta$-конвергенция.

\section{References}

1. Young, A. Sigma Convergence Versus Beta Convergence: Evidence from U.S. Countylevel Data / A. Young, M. Higgins, D. Levy // Journal of Money, Credit and Banking. - 2008. - V. 40, № 5. - P. 1083-1093.

2. De Michelis, N. Regional Convergence: a Relevant Measure of Policy Success? N. De Michelis // CESifo Forum. - 2008. - № 1. - P. 10-13.

3. Коломак, Е. А. Модели региональной политики: конвергенция или дивергенция / Е. А. Коломак / Вестник НГУ. Серия "Социально-экономические науки". 2009. - T. 9, № 1. - C. 113-120.

4. Неравномерность и цикличность динамики социально-экономического развития регионов: оценка, анализ, прогнозирование / под ред. Т. С. Клебановой, Н. А. Кизима. - Харьков: ИД "ИНЖЭК 2012. - 512 с. 
5. Сторонянська, I. Регіональний розвиток Украіни: проблеми інтеграціі та конвергенціi / I. Сторонянська. - Львів: Інститут регіональних досліджень НАН Украіни, 2010.

6. Solow, R. M. A Contribution to the Theory of Economic Growth / R. M. Solow // The Quarterly Journal of Economics. - 1956. - V. 70, № 1. - P. 65-94.

7. Mankiw, G. A. Contribution to the Empirics of Economic Growth / G. A. Mankiw, D. Weil, D. Romer // Quarterty Journal of Economics. - 1992. - V. 107, № 2. P. 407-438.

8. Barro, R. J. Economic Growth and Convergence across the United States / R. J. Barro, X. Sala-i-Martin // NBER Working Paper 3419. - Cambridge, NBER, 1990.

9. Толмачев, М. Н. Теоретические и эмпирические подходы к конвергенции сельскохозяйственного производств / М. Н. Толмачев // Вестник Волгоградского государственного университета. Серия 3 "Экономика. Экология". - 2012. - № 1 (20). C. $193-199$.

10. Romer, P. M. Increasing Returns and Long-Run Growth / P. M. Romer // Journal of Political Economy. - 1986. - V. 94, № 4. - P. 1002-1037.

11. Свободная энциклопедия Википедия. - URL: https://ru.wikipedia.org/ (дата обращения: 25 июня 2020)

12. Sala-i-Martin, X. Regional Cohesion: Evidence and Theories of Regional Growth and Convergence / X. Sala-i-Martin // European Economic Review. - 1996. - V. 40, № 6. P. $1325-1352$.

13. Sala-i-Martin, X. The Classical Approach to Convergence Analysis / X. Sala-iMartin // The Economic Journal. - 1996. - V. 106, № 473. - P. 1019-1036.

14. Изард, У. Методы регионального анализа: введение в науку о регионах У. Изард. - М.: Прогресс, 1966. - 660 с.

15. Jacobs, J. The Economy of Cities / J. Jacobs. - New York: Vintage Books, 1969.

16. Головина, С. Г. Оценка процессов конвергенции (дивергенции) в развитии районов Курганской области / С. Г. Головина, С. В. Пугин // Вестник Алтайского государственного аграрного университета. - 2014. - № 12 (122). - С. 162-166.

17. Henderson, J. V. Marshall's Scale Economies / J. V. Henderson // Journal of Urban Economics. - 2003 .- V. 53, № 1. - P. 1-28.

Криворотов Вадим Васильевич, доктор экономических наук, профессор, кафедра "Экономическая безопасность производственных комплексов", Уральский федеральный университет имени первого Президента России Б.Н. Елъиина (г. Екатеринбург, Российская Федераиия), v_krivorotov@mail.ru. 
Мохов Вениамин Геннадъевич, доктор экономических наук, профессор, кафедра "Прикладная экономика", Южно-Уральский государственный университет (ә. Челябинск, Российская Федерачия), mokhovvg@susu.ru.

Иванова Ольга Юръевна, доктор экономических наук, доцент, сектор "Проблемы регионального развития и децентрализации", Научно-исследовательский центр индустриалъных проблем развития НАН Украины (г. Харъков, Украина), laptevaou@gmail.com

Полякова Ольга Юръевна, кандидат экономических наук, доцент, сектор "Макроэкономический анализ и прогнозирование", Научно-исследовательский центр индустриальных проблем развития НАН Украины (ә. Харъков, Украина), polya_o@ukr.net

Поступила в редакиию 7 мая 2020 г. 